UDC 378.147:664-051

DOI: $10.31470 / 2415-3729-2018-8-27-44$

\title{
Professional Training of Modern Engineer-Pedagogue in the Field of Food Technologies in the System of Competency Approach's Pedagogical Categories
}

\section{Nataliia Volkova}

Doctor of Philosophy in Pedagogy (PhD), Assistant Professor Assistant Professor of the Department of Pedagogy and Methods of Technological Education, Kryvyi Rih State Pedagogical University, $\triangle 54$, Haharina Ave., Kryvyi Rih, Dnipropetrovsk region, Ukraine, 50000

E-mail: volkovanatali1802@gmail.com ORCID: 0000-0002-4864-8653

\section{Професійна підготовка сучасного інженера-педагога у галузі харчових технологій в системі педагогічних категорій компетентнісного підходу}

\section{Наталія Валентинівна Волкова}

кандидат педагогічних наук, доцент

доцент кафедри педагогіки та методики технологічної освіти, Криворізький державний педагогічний університет, $\triangle$ проспект Гагаріна, 54, м. Кривий Ріг, Дніпропетровська область, Україна, 50000

Дата надходження статті: 03 серпня 2018 р. Стаття прийнята до друку: 25 листопада 2018 р.

\section{Abstract}

The presented publication substantiates the peculiarities of the proffesional training of modern engineer-pedagogues in the 
field of food technologies in the system of competency approach's pedagogical categories. The benefits of this study are the regularities of the given process, analyzed by the author of the article. Moreover, the author has identified these regularities as the following: the correspondence of the learning process, the interconnection and interdependence of teaching and learning, the construction of the training's content in accordance with the objectives, the provision of interdisciplinary connections between different educational subjects, the unity of education and upbringing. The problem of designing the content part of education is revealed and the main positions in methodological concepts are singled out in the article. It is also noted by the author of the article that the educational process in the higher education institution should be directed to fixed laws and principles. With regard to higher pedagogical education, some knowledge-based learning principles are defined in the article; the author noted that they form a certain system of initial requirements, the observance of which ensure the necessary effectiveness of the educational process. Accordingly, the main principles for the proffesional training of future engineer-pedagogies in the field of food technologies on the basis of a competency approach are defined by the author as: the principle of training's professional orientation, the principle of scientificity, the principle of systemicity and consistency, the principle of directing the learning process on the personality of the learning's subject, the principle of consciencity and creative activity of the person in the learning process. The requirements for the engineer-pedagogies of the XXI century are also quite widely presented in the article by the author. In the author's opinion, these requirements' condition is the transformation of the vector of pedagogical staff's vocational training, based on a competence-oriented approach, involving the reorientation of the educational paradigm from a predominantly broadcast of knowledge to the formation of professionally relevant skills and competences for future engineer-pedagogies in the field of food technologies.

Key words: vocational preparation, engineer-and-pedagogies in the field of food technologies, principles of learning, requirements, competence, professional orientation. 


\section{References}

1. Vasilevskaya, E. A. (2000). Professionalnaya napravlennost obucheniya vyisshey matematike studentov tehnicheskih vuzov [Professional Direction of Teaching Higher Mathematics to Students of Technical Universities]. Extended abstract of candidate's thesis. Moskva [in Russian].

2. Horbatiuk, R. M., Volkova, N. V. (2018). Intehratsiia profesiinoi osvity i vyrobnytstva yak chynnyk modernizatsii pidhotovky maibutnikh inzheneriv-pedahohiv $\mathrm{u}$ haluzi kharchovykh tekhnolohii [Integration of vocational education and production as a factor of modernizing the training of future engineer educators in the field of food technologies]. Ukrainian Journal of Educational Studies and Information Technology, 6(1), 89-102. Retrieved from http://ojs. mdpu.org.ua/index.php/itse/article/view/2447/3059 [in Ukrainian].

3. Dyachenko, M. I. \& Kandyibovich, L. A. (1981). Psihologiya vyisshey shkolyi [Psychology of Higher Education]. Minsk : Izd-vo BGU [in Russian].

4. Kaganov, A. B. (1983). Rozhdenie spetsialista. Professionalnoe stanovlenie studenta [Birth of a specialist. Professional formation of a student]. Minsk : Izd-vo BGU [in Russian].

5. Lazarev, V. S. (2002). O razvivayuschihsya pedagogicheskih sistemah [On developing educational systems]. Pedagogika Pedagogics, 8. 20-27 [in Russian].

6. Lebedev, V. V. (2007). Strukturirovanie kompetentsiy perspektivnoe napravlenie $\mathrm{V}$ reshenii problem obrazovaniya [The structuring of competencies is a promising direction in solving the problems of education]. Shkolnyie tehnologii - School technologies, 2, 14-19 [in Russian].

7. Nizamov, R. A. (1975). Didakticheskie osnovyi aktivizatsii uchebnoy deyatelnosti [Didactic bases for the revitalization of learning activities]. Kazan : KGU [in Russian].

8. Novikov, A. M. (2000). Problemyi gumanizatsii professionalnogo obrazovaniya [Problems of the humanization of vocational education]. Pedagogika - Pedagogics, 9, 410 [in Russian].

9. Plotnikova, S. V. (2000). Professionalnaya napravlennost obucheniya matematicheskim distsiplinam studentov tehnicheskih 
vuzov [Professional orientation of teaching technical universities' students mathematical disciplines]. Candidate's thesis. Samara [in Russian].

\section{Вступ}

Технологічна модернізація вищої професійної освіти передбачає значні зміни у змісті та методиці освітнього процесу. Від сучасного закладу вищої освіти потрібно впровадження нових підходів до навчання, що забезпечують, поряд із його фундаментальністю, розвитку особистості, реалізацію освітніх потреб на основі потенційної багатоваріантності змісту та організації освітнього процесу засобами сучасних педагогічних технологій. Однак на сьогоднішній день не в повній мірі вирішені завдання щодо формування професійних компетенцій, вимірювань і оцінки рівня сформованості багатофункціональних і різноспрямованих характеристик.

Виходячи 3 якісних характеристик нової освітньої парадигми, вектор сучасного освітнього процесу отримує інший напрям у формуванні цілей, завдань і змісту професійної освіти, яке задає все більш різноманітний спектр кінцевих результатів професійної підготовки у зв’язку 3 розширенням горизонтів професійної діяльності майбутніх інженерів-педагогів. Досліджуючи сучасні проблеми професійної підготовки інженерівпедагогів у галузі харчових технологій, необхідно відзначити, що на рівні вищої школи особливої актуальності набуває питання зміни структурно-змістових характеристик освітнього процесу. Основним завданням його організації $є$ формування професійно компетентного інженера-педагога в галузі харчових технологій, здатного вирішувати різні завдання, в тому числі, 3 високим ступенем інноваційної домінанти в професійній діяльності.

Удосконалення освіти є безперервним процесом, оскільки сучасні темпи розвитку соціуму пред'являють освітній системі нові вимоги, які часто суперечать завданням педагогічної дійсності та іiі результативним характеристикам. Динамічний стан суспільства і положення в ньому особистості вимагають вагомих змін у системі освіти. Так, активне долучення молоді в сучасні суспільні та виробничі відносини є значно складнішим завданням, 
оскільки його вирішення відбувається в умовах глибоких соціально-економічних трасформацій.

На сьогоднішній день існує значна кількість психологопедагогічних досліджень (В. Беспалько, І. Блауберг, В. Сластьонін, Є. Шиянов та ін), в яких розкриваються проблеми вдосконалення освіти. Висвітленню проблеми професійної підготовки фахівців присвячені роботи вітчизняних і закордонних авторів: С. Гончаренка, І. Зязюна, Н. Кузьміної, О. Пєхоти, В. Семиченка та ін. Аналіз філософської, психологічної та педагогічної літератури 3 проблеми професійної підготовки майбутніх фахівців засвідчує, що в сучасній науці представлені дослідження різних іiі аспектів: теоретичні основи підготовки майбутнього фахівця (А. Алексюк, М. Васильєва, Р. Горбатюк, В. Гриньов, О. Гура, В. Євдокимов, Л. Кайдалова, В. Кремень, В. Лєдньов, В. Лозова, О. Мещанінов, І. Прокопенко, С. Сисоєва, Т. Сущенко, Г. Яворська та ін.).

У професійній освіті спрямованість загальнодактичної складової навчання майбутніх інженерів-педагогів у галузі харчових технологій на формування особистості фахівця до кінця ще не вивчена.

Метою статті є обгрунтування основних засад формування професійної підготовки майбутніх інженерів-педагогів у галузі харчових технологій на засадах компетентністного підходу в педагогічних закладах вищої освіти.

\section{Матеріал і методи дослідження}

Для досягнення поставленої мети у ході дослідження було використано низку методів наукового пошуку, зокрема - аналіз, синтез, узагальнення та систематизація наукової літератури.

\section{Результати та їх обговорення}

Домінуюче місце в методологічних концепціях, які формують цілі модернізації освіті, займає проблема проектування змістової частини освіти. Так, в процесі вивчення перспектив сучасної професійного професійної освіти О. Новіков виокремлює чотири основних позиції:

- перша (на рівні «освіта-особистість») - полягає в необхідності гуманізації професійної освіти, що реалізується у відході від технократичної мети забезпечення виробничої 
сфери кадрами, формування механізмів їх пристосування до виробництва, переорієнтації на гуманістичні цілі професійного становлення і розвитку кожної особистості;

- друга (на рівні «освіта-суспільство») - передбачає демократизацію професійної освіти шляхом формування умов для кожного суб'єкта освітнього процесу якомога повніше розкрити свій потенціал, можливості та здібності;

- третя (на рівні «освіта-виробництво») - детермінує випереджувальний вектор професійної освіти, тобто необхідність випередження рівня загальної та професійної освіти людей, представлення їх професійно значущих якостей щодо запитів виробництва, його техніко-технологічного забезпечення;

- четверта (на рівні «безперервна освіта») випливає 3 рефлексії категорії «освіта через усе життя» (Новиков, 2000:3).

Таким чином, дослідник зазначає, що в якісній професійній освіті зацікавлені не тільки члени суспільства чи суспільство в цілому, а також соціально-економічна сфера, в якій буде працювати майбутній інженер-педагог у галузі харчових технологій.

У дисертаційному дослідженні С. Плотнікова сформулювала цілі професійної освіти, які відповідають вимогам споживачів освітніх послуг:

1) створення умов для здійснення професійної діяльності, отримання кваліфікації та подальшого включення особистості в суспільно-корисну працю, виходячи з ї особистісних інтересів і здібностей;

2) забезпечення умов для виховання соціально-активних, творчих людей, які засвоїли на особистісному рівні систему загальнолюдських і національних цінностей та ідеалів, здатних і готових до покращення виробництва, виробничо-економічних i суспільних відносин;

3) формування кваліфікованих фахівців, які відповідають запитам виробництва в різних сферах, компетентність яких спрямрвана на широкий загальноосвітній і професійний кругозір, професійну мобільність (Плотникова, 2000:13).

Досягнення цих цілей потребує перегляду багатьох критеріїв професійної освіти: змісту, форм, методів і засобів навчання та виховання студентів, методичної системи викладання. 
Науковому обгрунтуванню побудови освітнього процесу в закладах вищої освіти (ЗВО) присвячені роботи С. Архангельского, В. Беспалька, І. Блауберга та ін. В їх роботах виокремлено такі закономірності даного процесу:

- відповідність процесу навчання формуванню всебічно розвиненого, творчо активного i компетентного фахівця, що відповідає запитам сучасного суспільства та виробництва;

- взаємозв'язок і взаємозалежність викладання і навчання як компонентів цілісності процесу навчання;

- підбір змісту навчання відповідно до завдань, що відображають вимоги до сучасного інженера-педагога в галузі харчових технологій;

- забезпечення міжпредметних зв'язків між різними циклами навчальних дисциплін, а також між дисциплінами всередині окремого циклу;

- включення в навчальну діяльність студента творчого підходу на весь період навчання;

- єдність навчання і виховання в освітньому процесі.

Отже, освітній процес у ЗВО повинен підпорядковуватися певним закономірностям i принципам. Стосовно педагогічної освіти у вищій школі значними $є$ наукозмістовні принципи навчання, які становлять певну систему вихідних вимог, дотримання яких забезпечує необхідну ефективність освітнього процесу.

Особливість принципів навчання полягає в представленні нормативних вимог до організації освіти і подальшого процесу здійснення освітньої діяльності ЗВО. Оскільки принципи навчання в межах професійної освіти мають свою специфіку, то не зовсім правильно говорити про ступінь вагомості того чи іншого принципу. Важливо не розглядати їх окремо один від одного, потрібно наголошувати їхньому співіснуванні, безперервній взаємодії. Відповідно, основними принципами навчання майбутніх інженерів-педагогів у галузі харчових технологій на засадах компетентнісного $є$ :

- принции професійної спрямованості який максимально спрямовує зміст навчальних дисциплін до змісту майбутньої професії. Даний принцип актуалізує необхідність введення 
методичних елементів викладання соціокультурних і психологопедагогічних дисциплін у спеціальні навчальні дисципліни;
- принциип
спрямованості
навчання
забезпечує

усвідомлення студентами, що фундаментальні теоретичні знання повинні супроводжуватися практичними знаннями і вміннями;

- принцип науковості навчання розкриває закономірність взаємодії між змістом засвоюваної студентом науки і конкретної навчальної дисципліни;

- принциип системності $i$ послідовності, що актуалізує необхідність структуризації змісту навчальної дисципліни за заданою дидактичною системою і логікою; ротацію знань в різних розділах дисципліни для вирішення нових завдань; опору на отриману раніше інформацію;

- принции орієнтації процесу навчання на особистість суб'єкта навчання. Даний принцип висуває такі вимоги до побудови освітнього процесу: виявлення здібностей студентів та їх особливостей, як суб'єктів освітнього процесу; прийняття їх суб'єктивного досвіду як самоцінності; побудова педагогічної взаємодії 3 максимальною опорою на суб'єктивний досвід, постійне узгодження в ході навчання;

- принции свідомості і творчої активності в навчанні орієнтований на визнання значущості суб'єктності в освітньому процесі. В основу принципу свідомості і творчої активності покладено умови, пов'язані 3 організацією свідомого навчання; забезпечення чіткого уявлення $\mathrm{i}$ розуміння цілей i завдань майбутньої професійної діяльності; виховання у студентів творчого ставлення до навчально-професійної діяльності; розвиток особистої ініціативи і самостійності мислення.

Реалізація представлених принципів в освітньому процесі педагогічних ЗВО можлива за умови тісного взаємозв'язку. Всі вони одночасно проявляються в компонентах організації освітнього процесу, і становлять цілісний дидактичний комплекс. Окрім того, зазначені принципи дозволяють враховувати i реалізовувати актуальні на сьогоднішній день тенденції в системі професійної освіти, які задають вектор гуманістичної спрямованості навчання. 
Проте, не дивлячись на часто змінні вимоги до технологодидактичного забезпечення професійної освіти провідне завдання вищої школи полягає в подготовці висококваліфікованих фахівців певних професій. Тому в контексті нашого дослідження особливе місце займає розгляд традиційного принципу професійної спрямованості освіти, в основу якої покладено педагогічний процес ЗВО.

Науковий континуум проблеми професійної спрямованості освіти має місце в широкому спектрі досліджень як вченихпедагогів, психологів, викладачів- предметників.

Поняття принципу професійної спрямованості навчання у вищій школі вперше використав Р. Нізамов. Однак автор не зміг обгрунтувати мотиви використання цього принципу в освітній практиці (Низамов, 1975). Вирішуючи питання професійної освіти в технічному університеті А. Каганов (Каганов, 1983), обгрунтовує значимість принципу професійної спрямованості у зв'язку 3 необхідністю введення в процес навчання елементів майбутньої професійною діяльністю. Дослідник, як наочний приклад наводить зустрічі студентів із провідними фахівцями, які дають забезпечують усвідомлений інтерес до обраної спеціальності.

Під професійною спрямованістю навчання розуміємо зміст навчального матеріалу та організацію його засвоєння в таких формах і видах діяльності, які відповідають системній логіці побудови навчального курсу i моделюють (імітують) пізнавальні та практичні завдання майбутньої професійної діяльності фахівця. Принцип професійної спрямованості повинен не тільки орієнтувати освітній процес на зв'язок з виробничим навчанням, але й охоплювати теоретичне навчання, організацію міждисциплінарних зв'язків, вводити професійні аспекти в процес навчання.

У дисертаційному дослідженні С. Плотнікова зазначає, що принцип професійної спрямованості суперечить принципу зв'язку теорії з практикою, однак він (зв'язок) дозволяє, крім орієнтації на виробниче навчання, поєднати теоретичне навчання 3 міждисциплінарними зв'язками загальних i спеціальних дисциплін (Плотникова, 2000:24). Вивчаючи принцип професійної 
спрямованості навчання науковець приходить до думки про своєрідне використання педагогічних засобів, що забезпечить заданий рівень засвоєння студентами передбачених навчальними програмами знань, умінь, навичок, i в той же час, успішне формування інтересу до професії, особистісні якості майбутнього фахівця. Педагогічні засоби, що забезпечують реалізацію принципу професійної спрямованості навчання, включають: характер ілюстративного матеріалу, способи його структуризації i подачі, використання нестандартних прийомів, методів і форм навчання.

Впровадження та подальша реалізація принципу професійної спрямованості навчання усуває суперечності між формуванням цілісного розвитку особистості i розвитком рівня iі професіоналізму, між теоретичною базою навчальних дисциплін і вмінням застосовувати отримані знання на практиці. Розвиваючи цю думку О. Василевська зазначає: «Принцип професійної спрямованості регулює в освіті співвідношення загального i специфічного, визначає діалектику взаємодії цілісного розвитку особистості та іiі особливого, професійного. Саме ця обставина визначає особливе дидактичне значення принципу професійної спрямованості в професійній освіті» (Василевская, 2000:28).

На наш погляд, зазначені вище підходи не виключають один одного, а дозволяють уточнити i розширити уявлення про принцип професійної спрямованості навчання, тому для всебічного розгляду цієї проблеми доречно їх поєднання.

Формування професійної спрямованості у студентів, на думку М. Дьяченка i Л. Кандибовича, передбачає зміцнення позитивного ставлення до майбутньої професії, інтересів, схильностей i здатності до неї. Дослідники вважають, що необхідно розвивати прагнення до вдосконалення своєї кваліфікації після закінчення ЗВО, задоволення матеріальних i духовних потреб, ідеалів, поглядів, переконань, формувати престиж професії (Дьяченко, \& Кандыбович, 1981).

Аналіз робіт вчених, в яких розглядаються різні напрями розробки i впровадження принципу професійної спрямованості навчання у вищій школі, виявив такі інваріантні компоненти 
сучасної професійної освіти, як професійну спрямованість освітнього процесу i професійну спрямованість формування особистості майбутнього фахівця на обрану професію. Цей висновок узгоджується 3 позицією про те, що для української вищої школи компетентністний підхід не $є$ новаторським, як для більшості європейських установ професійної освіти. Вважає, що на рівні системи освіти, так i конкретно в академічному середовищі 3ВО окремі конструкти компетентністного підходу завжди були обов'язковою частиною системи управління якістю освіти та професійної підготовки фахівців. Тому даний підхід не змінює традиційної, давно встановленої в українській вищій школі стратегії управління навчальними закладами, що передбачає орієнтацію на контроль іта оцінювання результатів навчання та виховання.

Однак на сучасному етапі розвитку нашої країни і світової економіки до професіоналізму майбутнього інженера-педагога в галузі харчових технологій пред'являються нові вимоги, що детермінують оновлення як методології, так і практики професійної освіти.

Так, під егідою ЮНЕСКО такими авторитетними міжнародними організаціями, як FEANI (Свропа) i ABET (Північна Америка), а також низкою національних професійногромадських організацій, розроблені вимоги до інженера-педагога XXI століття. Вони включають:

- стійкість, усвідомленість та позитивне ставлення до обраної професії, прагнення до постійного особистісного i професійного зростання, удосконалення суб'єктивного інтелектуального потенціалу;

- висока професійна компетентність, оволодіння усією базою значущих для професійної діяльності фундаментальних i спеціальних знань та практичних навичок;

- володіння моделюванням, прогнозуванням i проектуванням, а також методами досліджень i випробувань, необхідними для створення нових інтелектуальних цінностей i матеріальних продуктів;

- сформовану здатність творчого вирішення професійних завдань, вміння орієнтуватися в нестандартних 
умовах і позаштатних ситуаціях, здатність до аналізу проблем, самостійного опрацювання і реалізації плану необхідних дій;

- володіння методами техніко-економічного аналізу для раціоналізації, оптимізації та реновації технологічного процесу, а також методами екологічного забезпечення виробництва та захисту навколишнього середовища;

- високу комунікативну здатність і готовність до взаємодії в професійному та соціальному середовищах;

- розуміння динамічних тенденцій і провідних напрямів розвитку науки і техніки, науково-технічного прогресу, характеру впливу професійної діяльності на навколишнє середовище, на життєдіяльність людини і суспільства в цілому;

- цільність, світогляд, орієнтація на здоровий спосіб життя особистості фахівця як представника інтелігенції соціальнопрофесійної групи (Лазарєв, 2002).

У відповідності 3 цими вимогами інноваційне бачення професійної освіти в XXI столітті має спиратися на розуміння інтеграційного характеру професійної діяльності фахівця в сучасному суспільстві. Тому стратегічною метою професійної освіти $\epsilon$ розвиток у майбутнього інженера-педагога в галузі харчових технологій інтеграційних, аналітичних, дослідницьких, творчих здібностей, здатності до синтезу і здійснення нововведень техніко-економічного і соціального характеру, поповнення своїх знань і освоєння нових професійних умінь протягом усього трудового життя, швидкої адаптації до прискорених технологічних змін на світовому ринку.

Ці вимоги обумовлюють трансформацію вектора професійної підготовки педагогічних кадрів, в основу якого закладено компетентністно-орієнтований підхід, що передбачає орієнтацію освітньої парадигми 3 переважною трансляцією знань, формуванням професійно значущих умінь i навичок на створення умов для оволодіння майбутніми фахівцями комплексом компетенцій, які включають особистісний потенціал, здібності випускника ЗВО до стійкої життєвої і професійної діяльності в рамках сучасного багатофакторного соціально-політичного, ринково-економічного, інформаційнокомунікаційного простору. 
Компетентністний підхід спирається на певну сукупність загальних принципів виокремлення цілей освіти, відбору змісту навчання, організацію педагогічного процесу та оцінку освітніх результатів. До таких принципів в більшості науково-педагогічних джерел відносяться наступні положення:

- зміст професійної підготовки закладено в розвиток здібностей у студентів самостійно вирішувати навчальнопрофесійні задачі в різних сферах i видах діяльності на основі засвоєння соціального досвіду, елементом якого $є$ суб'єктивний досвід;

- зміст організації педагогічного процесу полягає у створенні умов для формування в студентів суб'єктивного досвіду самостійного вирішення пізнавальних, комунікативних, організаційних, моральних та інших завдань, що становлять зміст професійної підготовки майбутніх інженерів-педагогів у галузі харчових технологій.

На сьогоднішній день категоріальна база компетентністного підходу спирається на цілі і завдання освітнього процесу 3ВО, за яких компетенції задають вищий, узагальнений рівень сформованості в студентів умінь i навичок, а зміст освіти визначається базовими поняттями (знання, уміння, досвід творчої діяльності, досвід ціннісного ставлення тощо) (Лебедєв, 2007).

Суть гуманітаризації освіти визначається багатоаспектно: як засіб гуманізації освіти (у разі обгрунтування теорії та методології гуманізації освіти); в якості способу залучення до культурної спадщини; в якості процесу запозичення властивого гуманітарним наукам способу мислення, загальних підходів до об'єктів та їх пізнання; в якості способу перетворення професійної освіти в освіту, що базується на загальнолюдських цінностях.

Аналіз освітнього процесу у педагогічних ЗВО показує, що в основному реалізація гуманітаризації освіти відбувається через переорієнтацію міждисциплінарної взаємодії суспільствознавчих, мистецтвознавчих, технічних дисциплін на гуманітарну спрямованість, збільшення історико-культурних аспектів всередині загальноспеціальних профілюючих дисциплін, а також питомої ваги гуманітарних предметів у змісті професійної підготовки 
майбутніх інженерів-педагогів у галузі харчових технологій (Горбатюк, \& Волкова, 2018).

Реалізація напрямів гуманітаризації освіти пов'язана 3 низкою труднощів, зокрема: 3 визначенням співвідношення між гуманітарними i негуманітарними предметами, їх місцем в освітньому просторі, а отже, збільшенням або зменшенням частки гуманітарних дисциплін у загальній кількості годин навчального плану.

Опираючись на зазначене, розглядаємо гуманітаризацію освіти як основу формування у студента особливої гуманістичної форми відносин і ставлення до навколишнього світу, особистісну діяльність в соціумі. За такого розуміння гуманітаризації освіти зникає наявне сьогодні в педагогічних ЗВО протиставлення гуманітарних i природничо-наукових, спеціальних, технічних i технологічних дисциплін.

Вихід із сформованих протиріч пов'язаний 3 фундаменталізацією освіти, що надає можливість посилити взаємозв'язок теоретико-практичної підготовки майбутнього професіонала до сучасної життєдіяльності, забезпечити глибоке i системне освоєння науково-теоретичних знань 3 усіма дисциплінами навчального плану. Дані аспекти передбачають розширення фундаментальної теоретичної підготовки, що забезпечує формування компетентності майбутнього фахівця. Останнім часом в проблемне поле компетентності фахівця міцно ввійшло поняття «базисні кваліфікації». До них, в першу чергу, відносяться якості особистості, пов'язані із самостійною діяльністю, творчим підходом до роботи, наполегливістю як прагненням доводити розпочату справу про кінця, готовністю до особистісного i професійного самовдосконалення, гнучкістю розуму, здатністю до системного, економічного, екологічного мислення, вміння вести діалог, організувати i брати участь у колективній роботі. Необхідно актуалізувати увагу на необхідність оволодіння майбутніми фахівцями «наскрізними» вміннями, пов'язаними з роботою на комп'ютерах, користуванням базами і банками даних, спеціальними знаннями в області екології, економіки, бізнесу та фінансів, права та медицини. 
Іншими словами, важливо підготувати майбутні кадри не до вузько професійної, а до універсальної діяльності, яка динамічно змінюється в суспільстві. Важливо формувати у студентів пізнавальний інтерес до змісту професійної підготовки, розвивати здатність вчитися, вміти працювати 3 постійно зростаючим обсягом інформації, критично його оцінювати.

Гуманізація професійної освіти передбачає забезпечення iii діяльнісної спрямованості, суть якої полягає у формуванні траєкторії руху студентів від словесного рівня до предметного, від спостерігального до діяльнісно-операційного, від емпіричного до концептуального, від тематичного до проблемного, від гносеологічного до особістісного. Знаннєва парадигма професійного освіти, незважаючи на присутність в ній компетентністних основ, в тому вигляді, в якому вона функціонувала в освіті попередніх десятиріч, поступається місцем діяльнісного підходу, де на перший план виступає формування професійних компетенцій. Проте, використання виключно діяльнісного аспекту не передбачає націленості на формування активної особистості, яка вміє здобувати наукові знання, правильно визначати мету та умови вирішення (конкретні способи і засоби діiі) нестандартних задач навчально-професійної діяльності.

Безумовно, что в процесі підготовкі майбутніх інженерівпедагогів у галузі харчових технологій важливо постійно розвивати їх пізнавальні інтереси, 3 необхідністю активно i самостійно застосовувати знання у вирішенні навчальнопрофесійних завдань, ставити їх в ситуації, які вимагають активного прояву різноманітних особистісніх якостей.

\section{Висновки}

Виявлення основних передумов розвитку освітнього процесу в педагогічному ЗВО дозволяє побачити об'єктивну основу для організації умов, що стимулюють пізнавальну діяльність майбутніх інженерів-педагогів у галузі харчових технологій 3 оволодіння науковими знаннями, розвитку творчих здібностей, формування наукового світогляду і морально-естетичної культури, загальнокультурних і професійних компетенцій. У зв'язку з цим, доцільно розширювати в освітній програмі всі види навчальної діяльності, наближені до професійної. Таким чином, принцип професійної спрямованості навчання в умовах компетентністної 
парадигми освіти набуває домінуючого характеру, реалізуючись у навчальних практиках, навчально-дослідницькій роботі студентів, в процесі збагачення освітнього простору активними методами навчання (діловими, рольовими, імітаційними іграми, кейсовими завданнями тощо), збільшенням частки творчої самостійної роботи майбутніх фахівців у галузі харчових технологій. При цьому значущою умовою реалізації принципу професійної спрямованості навчання $\epsilon$ необхідність формування «цінніснозмістових компонентів компетентності майбутнього фахівця».

Перспективами подальших розвідок буде створення дієвих механізмів реалізації принципу професійної спрямованості навчання майбутніх інженерів-педагогів у галузі харчових технологій на засадах компетентністного підходу.

\section{Література}

1. Василевская Е. А. Профессиональная направленность обучения высшей математике студентов технических вузов: автореф. дис. на соискание научной степени канд. пед. наук : 13.00.08. Москва. 2000. 20 с.

2. Горбатюк Р. М., Волкова Н. В. Інтеграція професійної освіти і виробництва як чинник модернізації підготовки майбутніх інженерів-педагогів у галузі харчових технологій. Ukrainian Journal of Educational Studies and Information Technology. 2018. Tом 6. № 2. C. 89-102 URL : http://ojs.mdpu.org.ua/index.php/itse/ article/view/2447/3059.

3. Дьяченко М. И., Кандыбович Л. А. Психология высшей школы. Минск : Изд-во БГУ. 1981. С. 22-28.

4. Каганов А. Б. Рождение специалиста. Профессиональное становление студента. Минск : Изд-во БГУ. 1983. 220 с.

5. Лазарєв В. С. О развивающихся педагогических системах. Педагогика. 2002. № 8. С. 20-27.

6. Лебедєв В. В. Структурирование компетенций перспективное направление в решении проблем образования. Школьныле технологии. 2007. № 2. С. 14-19.

7. Низамов Р. А. Дидактические основы активизации учебной деятельности. Казань : КГУ. 1975. 340 с.

8. Новиков А. М. Проблемы гуманизации профессионального образования. Педагогика. 2000. № 9.410 с. 
9. Плотникова С. В. Профессиональная направленность обучения математическим дисциплинам студентов технических вузов: дисс. ... канд. пед. наук : 13.00.08. Самара. 2000. 186 с.

\section{Волкова Н. В.}

Професійна підготовка сучасного інженера-педагога у галузі харчових технологій в системі педагогічних категорій компетентнісного підходу

\section{Аннотация}

В представленной публикации осуществлена попытка обосновать особенности профессиональной подготовки современного инженера-педагога в области пищевых технологий. Проанализированы такие закономерности данного процесса как: соответствие процесса обучения, взаимосвязь и взаимозависимость преподавания и обучения, подбор содержания обучения в соответствии с задачами, обеспечение межпредметных связей между различными циклами учебных дисциплин, единство обучения и воспитания. Раскрыта проблема проектирования содержательной части образования и выделены основные позиции в методологических концепциях.

Ключевые слова: професиональная подготовка, инженерыпедагоги в области пищевых технологий, принцыпы обучения, компетенции, професиональная направленность.

Волкова Н. В.

Професійна підготовка сучасного інженера-педагога у галузі харчових технологій в системі педагогічних категорій компетентнісного підходу

\section{Анотація}

У представленій публікації здійснена спроба обгрунтувати особливості професійної підготовки сучасного інженера-педагога 
в області харчових технологій. Проаналізовані такі закономірності даного процесу як: відповідність процесу навчання, взаємозв'язок i взаємозалежність викладання i навчання, підбір змісту навчання відповідно до завдань, забезпечення міжпредметних зв’язків між різними циклами навчальних дисциплін, єдність навчання i виховання. Розкрита проблема проектування змістової частини освіти та виокремлено основні позиції в методологічних концепціях.

Ключові слова: професійна підготовка, інженери-педагоги у галузі харчових технологій, принципи навчання, компетенції, професійна спрямованість. 